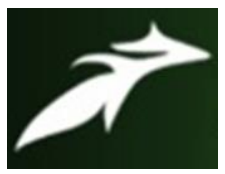

Annepu Priyanka et al, International Journal of Advances in Agricultural Science and Technology,

Vol.7 Issue.11, November-2020, pg. 28-37

ISSN: 2348-1358

Impact Factor: 6.057

NAAS Rating: 3.77

\title{
"IMPACT OF KVK TRAININGS ON KNOWLEDGE OF PADDY GROWERS" CASES FROM SRIKAKULAM DISTRICT OF ANDHRA PRADESH
}

\author{
${ }^{1}$ Annepu Priyanka; ${ }^{2}$ Dr. Dipak Kumar Bose; ${ }^{3}$ Dr. Jahanara \\ ${ }^{1}$ M.Sc.Ag(Agricultural Extension \& Communication) Final Sem \\ ${ }^{2}$ Associate Professor \\ ${ }^{3} \mathrm{HOD}$ \\ Department of Agricultural Extension and Communication \\ Sam Higginbottom University of Agricultural Technology and Sciences, Prayagraj (211007)
}

DOI: 10.47856/ijaast.2020.v07i11.005

\begin{abstract}
The impact of training programmes of KVK, Srikakulam that consists of trained and untrained respondents of paddy growers, knowledge is the cognitive component of individuals mind and plays an important role convert as well as overt behaviour and individuals with a grater knowledge of technical nature of improved practices, and the study was conducted under KVK, Amadalavalasa, in srikakulam district. The data were collected through personal interview method using structured schedule. The Expost facto research design was employed in the present investigation. Most of the trained paddy growers had an equal percentage of medium (43.33\%) and high (43.33\%) level of knowledge, followed by low (13.34\%) level of knowledge. More than half of the untrained paddy growers (58.33\%) had medium level of knowledge, followed by low (26.67\%) and high (15\%) level of knowledge. In comparison with untrained paddy growers, trained paddy growers had high level of knowledge regarding the new techniques and practices, scientific methods and newly released varieties.
\end{abstract}

Keywords: Krishi Vigyan Kendra, Training, Knowledge.

\section{INTRODUCTION}

The concept of Krishi Vigyan Kendra was framed by Professor Swaminathan, Father of Agriculture Research of India. Professor M S Swaminathan convinced Government of India that there is absolute necessity to develop Krishi Vigyan Kendra in each district of India with an objective to cater following Mandate and Activities for the farming community of the District Usually associated with a local agricultural university, these centers serve as the ultimate link between the Indian Council of Agricultural Research and farmers, and aim to apply agricultural research in a practical, localized setting. All KVKs fall under the jurisdiction of one of the 11 Agricultural Technology Application Research Institutes (ATARIs) throughout India. The first 


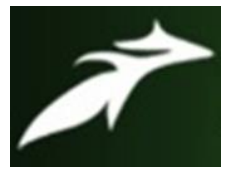

Annepu Priyanka et al, International Journal of Advances in Agricultural Science and Technology,

Vol.7 Issue.11, November-2020, pg. 28-37

ISSN: 2348-1358

Impact Factor: 6.057

NAAS Rating: 3.77

KVK, on a pilot basis, was established in 1974 at Puducherry (Pondicherry) under the administrative control of the Tamil Nadu Agricultural University, Coimbatore. At present As of January 2020, there were approximately there are 721 KVKs throughout India, out of which 498 are under State Agricultural Universities (SAU) and Central Agricultural University (CAU), 66 under ICAR Institutes, 104 under NGOs, 38 under State Governments, and the remaining under other educational institutions.

Since then, KVKs have been established in all states, and the number continues to grow. The Indian agricultural landscape faces many challenges, including a high percentage of smallholder farmers, lack of supply chain infrastructure, and extreme weather conditions. For a full description of these challenges, see Agriculture in India. A key strategy in addressing these issues, in addition to policy support and a functioning market, is using technology to better understand and adapt to complex challenges.

\section{RESEARCH METHODOLOGY}

The state of Andhra Pradesh was chosen for the study purposively as the researcher belonged to this state and well acquainted with the regional language which would build up a good rapport and also facilitates in depth study through personal observation. And Ex- post facto design was followed for the analysis. This design was considered appropriate because we were studying the phenomenon that has already occurred. Ex- post facto design is a quasi-experimental study examining how an independent variable, present prior to the study in the participants, affects a dependent variable. Srikakulam district of Andhrapradesh is selected purposively because paddy is the major crop and has potentially growing hear and conducted lot of trainings, and this KVK was zonal award winning $\mathrm{KVK}$, the research belongs to the district hence the srikakulam district is selected for study. There are 38 taluks in the selected district out of that Amadalavalasa taluk was selected purposively, due to the presence of adequate number of paddy trainers and nontrainers. There are 39 villages in Amadalavalasa, out of that six villages were selected purposively based on maximum area under paddy cultivation. A total of 120 farmers were selected randomly out of which 60 were trainees and 60 were non- trainees. In order to find out the distribution of the respondents according to their level of knowledge and to measure the significance of difference between the mean score of knowledge, a knowledge test was developed. While administering the final knowledge test, score ' 1 ' (one) was assigned for a 


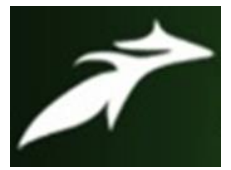

Annepu Priyanka et al, International Journal of Advances in Agricultural Science and Technology,

Vol.7 Issue.11, November-2020, pg. 28-37

ISSN: 2348-1358

Impact Factor: 6.057

NAAS Rating: 3.77

correct answer and score ' 0 ' (zero) was assigned for an incorrect answer. Total number of questions to test the knowledge level of the respondent. were 25 and thus, a respondent could score maximum 25. The score so obtained under various questions were summed up. On the basis of the total score obtained, respondents were categorized into three classes i.e. low, medium and high level of knowledge using the procedure followed by Dasgupta (1989).

Finally, paired ' $t$ ' test was used to test the significance of differences in knowledge gained on before and after basis. The relation of a set of selected independent variables with knowledge gained was also examined.

\section{RESULTS AND DISCUSSION}

Table 1: Socio-economic profile of the respondents

$(\mathbf{N}=\mathbf{1 2 0})$

\begin{tabular}{|c|c|c|c|c|c|c|}
\hline \multirow{3}{*}{ S.No } & \multirow{3}{*}{ Characteristics } & \multirow{3}{*}{ Category } & \multicolumn{4}{|c|}{ Response } \\
\hline & & & \multicolumn{2}{|c|}{ Trained paddy growers } & \multicolumn{2}{|c|}{ Untrained paddy growers } \\
\hline & & & $F$ & $\%$ & $F$ & $\%$ \\
\hline \multirow{3}{*}{1.} & \multirow{3}{*}{ Age (in years) } & Young (<30 years) & 7 & 11.67 & 7 & 11.67 \\
\hline & & Middle (31-45 years) & 22 & 36.67 & 13 & 21.67 \\
\hline & & Old $(>45$ years $)$ & 31 & 51.66 & 40 & 66.66 \\
\hline & & Illiterate & 13 & 21.67 & 14 & 23.33 \\
\hline & & Primary school & 14 & 23.33 & 15 & 25.00 \\
\hline & & Upper primary school & 13 & 21.67 & 11 & 18.33 \\
\hline
\end{tabular}




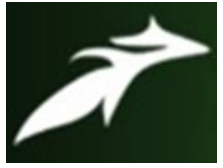

Annepu Priyanka et al, International Journal of Advances in Agricultural Science and Technology, Vol.7 Issue.11, November-2020, pg. 28-37

ISSN: 2348-1358

Impact Factor: 6.057

NAAS Rating: 3.77

\begin{tabular}{|c|c|c|c|c|c|c|}
\hline \multirow[t]{3}{*}{2.} & \multirow[t]{3}{*}{ Education level } & High school & 8 & 13.33 & 10 & 16.67 \\
\hline & & Intermediate & 7 & 11.67 & 6 & 10.00 \\
\hline & & Under graduation & 5 & 8.33 & 4 & 6.67 \\
\hline \multirow{2}{*}{3.} & \multirow{2}{*}{ Family size } & $\begin{array}{l}\text { Small family } \quad(<4 \\
\text { members })\end{array}$ & 37 & 61.67 & 42 & 70.00 \\
\hline & & $\begin{array}{l}\text { Large family } \quad(>\quad 4 \\
\text { members })\end{array}$ & 23 & 38.33 & 18 & 30.00 \\
\hline \multirow{3}{*}{4.} & \multirow{3}{*}{$\begin{array}{l}\text { Land holding } \\
\text { (in acres) }\end{array}$} & $1-3$ acres & 22 & 36.67 & 21 & 35.00 \\
\hline & & 4- 6 acres & 26 & 43.33 & 30 & 50.00 \\
\hline & & Above 7 acres & 12 & 20.00 & 9 & 15.00 \\
\hline \multirow{3}{*}{5.} & \multirow{3}{*}{ Annual Income } & Low & 21 & 35.00 & 22 & 36.67 \\
\hline & & Medium & 28 & 46.67 & 25 & 41.67 \\
\hline & & High & 11 & 18.33 & 13 & 21.66 \\
\hline \multirow{3}{*}{6.} & \multirow{3}{*}{$\begin{array}{l}\text { Source of } \\
\text { irrigation }\end{array}$} & Bore well & 18 & 30.00 & 13 & 21.67 \\
\hline & & Canal & 28 & 46.67 & 29 & 48.33 \\
\hline & & Pond & 14 & 23.33 & 18 & 30.00 \\
\hline \multirow{3}{*}{7.} & \multirow{3}{*}{$\begin{array}{l}\text { Social } \\
\text { participation }\end{array}$} & Low & 8 & 13.34 & 14 & 23.33 \\
\hline & & Medium & 26 & 43.33 & 28 & 46.67 \\
\hline & & High & 26 & 43.33 & 18 & 30.00 \\
\hline & & & & & & \\
\hline & & & & & & \\
\hline
\end{tabular}




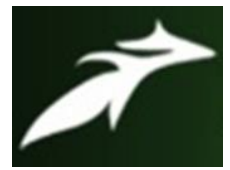

Annepu Priyanka et al, International Journal of Advances in Agricultural Science and Technology, Vol.7 Issue.11, November-2020, pg. 28-37

ISSN: 2348-1358

Impact Factor: 6.057

NAAS Rating: 3.77

\begin{tabular}{|l|l|l|l|l|l|l|}
\hline 8. & $\begin{array}{l}\text { Extension } \\
\text { contact }\end{array}$ & Low & 11 & 18.33 & 14 & 23.33 \\
\cline { 3 - 7 } & & Medium & 13 & 21.67 & 16 & 26.67 \\
\cline { 3 - 7 } & High & 36 & 60.00 & 30 & 50.00 \\
\hline \multirow{2}{*}{9.} & \multirow{2}{*}{$\begin{array}{l}\text { Mass media } \\
\text { exposure }\end{array}$} & Low & 6 & 10.00 & 7 & 11.67 \\
\cline { 3 - 7 } & Medium & 12 & 20.00 & 22 & 36.67 \\
\cline { 3 - 7 } & High & 42 & 70.00 & 31 & 51.66 \\
\hline
\end{tabular}

It can be seen that majority of the trained paddy growers were old (51.66\%). While in untrained paddy growers, majority of them belonged to old (66.66\%).Majority of the trained paddy growers had primary school education $(23.33 \%)$, followed by an equal percentage of illiterate $(21.67 \%)$ and upper primary school level of education $(21.67 \%)$. Whereas, one-fourth of the untrained paddy growers had primary school education $(25 \%)$, followed by illiterate $(23.33 \%)$, upper primary school (18.33\%). it was evident that majority of the trained paddy growers had small family (61.67\%). Whereas, among the untrained paddy growers, nearly three-fourth of the respondents had small family $(70 \%)$.

It can be seen that among the trained paddy growers majority of the paddy growers had a land holding of 4-6 acres (43.33\%). Among untrained paddy growers, half of them had 4-6 acres $(50 \%)$. It was observed that nearly half of the trained paddy growers had medium level of annual income (46.67\%). Whereas, among untrained paddy growers, most of them had medium level of annual income (41.67\%). it revealed that nearly half of the trained paddy growers $(46.67 \%)$ were using canal as the source of irrigation. Simultaneously, untrained paddy growers were using canal $(48.33 \%)$ for irrigation.

It can be learnt that trained paddy growers had an equal percentage of medium (43.33\%) and high (43.33\%) level of social participation. Among the untrained paddy growers had nearly half of them $(46.67 \%)$ had medium level of social participation. Trained paddy growers had 


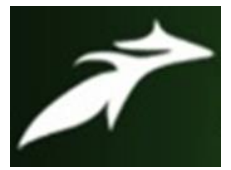

Annepu Priyanka et al, International Journal of Advances in Agricultural Science and Technology,

Vol.7 Issue.11, November-2020, pg. 28-37

ISSN: 2348-1358

Impact Factor: 6.057

NAAS Rating: 3.77

more social participation in comparison with untrained paddy growers. It indicated that more than half of the trained paddy growers $(60 \%)$ had high level of extension contact. Among the untrained paddy growers, half of the paddy growers had high level of extension contact (50\%). Trained paddy growers had high level of extension contact when compared with untrained paddy growers. It can be understood that nearly three-fourth (70\%) of the trained paddy growers had high level of mass media exposure. Whereas among the untrained paddy growers, more than half of them had high level of mass media exposure (51.66\%). In comparison with untrained paddy growers, trained paddy growers had high level of mass media exposure.

Table 2: Knowledge of the respondents towards improved paddy cultivation

$(\mathrm{N}=120)$

\begin{tabular}{|c|c|c|c|c|c|}
\hline \multirow[t]{2}{*}{ Sl.no } & \multirow[t]{2}{*}{ Knowledge of paddy growers } & \multicolumn{2}{|c|}{ Trainee response } & \multicolumn{2}{|c|}{ Non Trainee response } \\
\hline & & $\mathbf{F}$ & $\%$ & $\mathbf{F}$ & $\%$ \\
\hline 1. & $\begin{array}{l}\text { Wider spacing in paddy gives } \\
\text { higher yield than close } \\
\text { spacing. }\end{array}$ & 39 & 65 & 24 & 40 \\
\hline 2. & $\begin{array}{l}\text { White rectangular parallel } \\
\text { streaks on paddy leaves is } \\
\text { caused by Tungro virus. }\end{array}$ & 47 & 78.33 & 32 & 53.33 \\
\hline 3. & $\begin{array}{l}\text { Only 2-3 seedlings per hill } \\
\text { should be planted in main field } \\
\text { for high yield. }\end{array}$ & 41 & 68.33 & 26 & 43.33 \\
\hline 4. & $\begin{array}{l}\text { Allay ways in paddy decreases } \\
\text { the pest incidence }\end{array}$ & 40 & 66.67 & 30 & 50 \\
\hline 5. & $\begin{array}{l}\text { Recommended seed rate for } \\
\text { transplanted paddy per acre }\end{array}$ & 48 & 80 & 30 & 50 \\
\hline 6. & $\begin{array}{l}\text { The recommended nursery } \\
\text { area required for one acre of } \\
\text { main field is }\end{array}$ & 47 & 78.33 & 25 & 41.67 \\
\hline 7. & $\begin{array}{l}\text { The no.of seedlings to be } \\
\text { transplanted per hill is }\end{array}$ & 40 & 66.67 & 30 & 50 \\
\hline
\end{tabular}




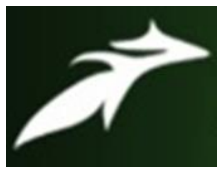

Annepu Priyanka et al, International Journal of Advances in Agricultural Science and Technology, Vol.7 Issue.11, November-2020, pg. 28-37

ISSN: 2348-1358

Impact Factor: 6.057

NAAS Rating: 3.77

\begin{tabular}{|c|c|c|c|c|c|}
\hline 8. & $\begin{array}{c}\text { Mention the optimum age of } \\
\text { seedlings to be transplanted in } \\
\text { SRI cultivation }\end{array}$ & 51 & 85 & 31 & 51.67 \\
\hline 9. & $\begin{array}{c}\text { What is seed rate required for } \\
\text { broad casting method of paddy } \\
\text { cultivation }\end{array}$ & 56 & 93.33 & 32 & 53.33 \\
\hline 10. & $\begin{array}{c}\text { Sheath blight disease can be } \\
\text { controlled by spraying }\end{array}$ & 48 & 80 & 37 & 61.67 \\
\hline 11. & $\begin{array}{c}\text { Clipping of leaf tips of } \\
\text { seedlings while transplanting } \\
\text { is done to control }\end{array}$ & 47 & 78.33 & 29 & 48.33 \\
\hline 12. & $\begin{array}{c}\text { Spindle shaped spots on leaf } \\
\text { indicate which disease in } \\
\text { paddy. }\end{array}$ & 47 & 78.33 & 31 & 51.67 \\
\hline 13. & $\begin{array}{c}\text { Mention the spacing for drum } \\
\text { seeder }\end{array}$ & 47 & 78.33 & 33 & 55 \\
\hline 14. & $\begin{array}{c}\text { Mention the pre emergence } \\
\text { weedicide in paddy }\end{array}$ & 46 & 76.67 & 28 & 46.67 \\
\hline 15. & $\begin{array}{c}\text { Water management level at } \\
\text { panicle emergence stage in } \\
\text { paddy field }\end{array}$ & 51 & 85 & 35 & 58.33 \\
\hline
\end{tabular}

Table 3: Distribution of respondents based on their knowledge level

$(\mathbf{N}=\mathbf{1 2 0})$

\begin{tabular}{|c|c|c|c|c|c|}
\hline \multirow{2}{*}{ S. No. } & \multirow{2}{*}{$\begin{array}{l}\text { Knowledge level of } \\
\text { paddy growers }\end{array}$} & \multicolumn{2}{|l|}{ Response } \\
\cline { 3 - 6 } & & $\boldsymbol{F}$ & $\%$ & $\boldsymbol{F}$ & $\%$ \\
\cline { 3 - 6 } & Low & 8 & 13.34 & 16 & 26.67 \\
\hline 1 & Medium & 26 & 43.33 & 35 & 58.33 \\
\hline 3 & High & 26 & 43.33 & 9 & 15.00 \\
\hline
\end{tabular}




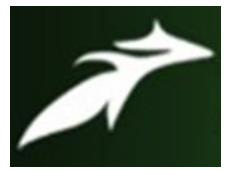

Annepu Priyanka et al, International Journal of Advances in Agricultural Science and Technology,

Vol.7 Issue.11, November-2020, pg. 28-37

ISSN: 2348-1358

Impact Factor: 6.057

NAAS Rating: 3.77

It can be seen that most of the trained paddy growers had an equal percentage of medium (43.33\%) and high (43.33\%) level of knowledge, followed by low (13.34\%) level of knowledge. More than half of the untrained paddy growers (58.33\%) had medium level of knowledge, followed by low (26.67\%) and high (15\%) level of knowledge. In comparison with untrained paddy growers, trained paddy growers had high level of knowledge regarding the new techniques and practices, scientific methods and newly released varieties.

\section{Table 4: Relationship between independent variables and knowledge level of trained and untrained paddy growers}

Relationship between independent variables and knowledge level of trained paddy growers

$(\mathbf{N}=120)$

\begin{tabular}{|l|l|l|l|l|l|}
\hline S. No. & Characteristics & $\begin{array}{l}\text { Regression } \\
\text { co-efficient }\end{array}$ & $\begin{array}{l}\text { Standard } \\
\text { error }\end{array}$ & t-value & p-value \\
\hline $\mathrm{X}_{1}$ & Age & 0.005 & 0.027 & $0.214 * *$ & 0.830 \\
\hline $\mathrm{X}_{2}$ & Education & -0.112 & 0.283 & $-0.397 * *$ & 0.692 \\
\hline $\mathrm{X}_{3}$ & Family size & 0.799 & 0.675 & 1.184 & $0.241^{* *}$ \\
\hline $\mathrm{X}_{4}$ & Land holding & -0.185 & 0.439 & $-0.422^{* *}$ & 0.674 \\
\hline $\mathrm{X}_{5}$ & Annual income & -0.093 & 0.465 & $-0.201 * *$ & 0.841 \\
\hline $\mathrm{X}_{6}$ & Source of irrigation & 0.052 & 0.447 & $0.117 * * *$ & 0.907 \\
\hline $\mathrm{X}_{7}$ & Social participation & 0.120 & 0.280 & $0.430^{* *}$ & 0.668 \\
\hline $\mathrm{X}_{8}$ & Mass media exposure & 0.262 & 0.313 & $0.338^{* *}$ & $0.405^{* *}$ \\
\hline $\mathrm{X}_{9}$ & Extension contact & 0.022 & 0.270 & $0.083^{*}$ & 0.933 \\
\hline
\end{tabular}

It can been seen that the variables like age and social participation had positive and significant relationship with knowledge level of trained paddy growers at 5 per cent level of significance. Whereas, education, annual income, mass media exposure and land holding were negatively 


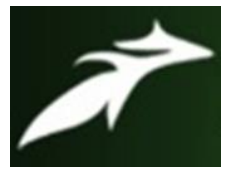

Annepu Priyanka et al, International Journal of Advances in Agricultural Science and Technology,

Vol.7 Issue.11, November-2020, pg. 28-37

ISSN: 2348-1358

Impact Factor: 6.057

NAAS Rating: 3.77

significant to knowledge level at 5 per cent level of significance. Consequently, extension contact was positively significant to knowledge level at 1 per cent level of significance and source of irrigation was positively significant to 10 per cent level of significance. Simultaneously, family size had no significant relationship with the knowledge level of trained paddy growers. Simultaneously, family size and mass media exposure were positively correlated to knowledge level of trained paddy growers.

Table 5: Relationship between independent variables and knowledge level of untrained paddy growers

$(\mathrm{N}=120)$

\begin{tabular}{|l|l|l|l|l|l|}
\hline S. No. & Characteristics & $\begin{array}{l}\text { Regression } \\
\text { co-efficient }\end{array}$ & $\begin{array}{l}\text { Standard } \\
\text { error }\end{array}$ & t-value & p-value \\
\hline $\mathrm{X}_{1}$ & Age & -0.019 & 0.025 & -0.754 & $0.454^{* *}$ \\
\hline $\mathrm{X}_{2}$ & Education & -0.128 & 0.223 & -0.575 & 0.567 \\
\hline $\mathrm{X}_{3}$ & Family size & -0.290 & 0.631 & $-0.459 * *$ & 0.647 \\
\hline $\mathrm{X}_{4}$ & Land holding & 0.367 & 0.418 & 0.878 & $0.383^{* *}$ \\
\hline $\mathrm{X}_{5}$ & Annual income & -0.042 & 0.385 & $-0.109 *$ & 0.913 \\
\hline $\mathrm{X}_{6}$ & Source of irrigation & 0.142 & 0.391 & $0.364 * *$ & 0.716 \\
\hline $\mathrm{X}_{7}$ & Social participation & 0.091 & 0.160 & 0.573 & 0.568 \\
\hline $\mathrm{X}_{8}$ & Mass media exposure & 0.393 & 0.226 & 1.733 & $0.089 *$ \\
\hline $\mathrm{X}_{9}$ & Extension contact & -0.045 & 0.180 & $-0.251 *$ & 0.802 \\
\hline
\end{tabular}

It can been observed that the variables like source of irrigation had positive and significant relationship with knowledge level of untrained paddy growers at 5 per cent level of significance. Whereas, family size was negatively significant to knowledge level at 5 per cent level of significance. Consequently, annual income and extension contact were negatively significant to knowledge level at 5 per cent level of significance. Simultaneously, age and land holding were positively correlated to 5 per cent level of significance and mass media exposure was positively correlated at 1 per cent level of significance. 


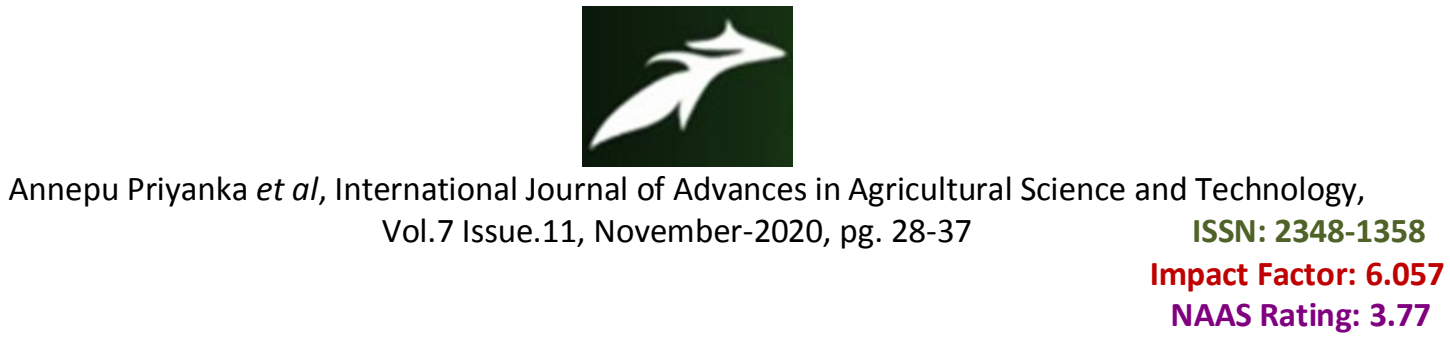

\section{CONCLUSION}

It was concluded that findings of the study that most of the farmers of the district On measuring the knowledge about KVK paddy trainers it was found that most of the trainees possessed has equal percent of medium and high level of knowledge and whereas most of non- trainees possessed medium level of knowledge. It can be concluded that KVK Training Programmes had influenced in enhancing the level of knowledge and technologies of paddy growers.

\section{REFERENCES}

[1]. Banumathy, S. (2003). An analysis on technological gaps and adoption of improved rainfed practices in rice. M.Sc. (Ag.) Thesis. AC\&RI, TNAU, Madurai.

[2]. Ganesan R and Seetalakshmi (2002) Participation Pattern of Women on IPM in Rice. Agricultural Extension Review (9-10): 28-30.

[3]. Gogoi, M., Phukan, E and Talukdar, R. K. (2000). Impact of Farmers Training Programme on Adoption of Rice Production Technology by Farmers. Maharashtra Journal of Extension Education. XIX: 232-238.

[4]. Parthasarathi S, and Santha Govind (2002) Knowledge of Trained and Untrained farmers on IPM practices. Journal of Extension Education 13 (1): 3293-3297.

[5]. Sagwal R C and Malik R S (2001) Knowledge Index of Rice Grower Farmer. Agricultural Extension Review (9-10) : 13-18. 